\title{
ANNANGGURU ABDURRAHMAN QADIR (Studi Biografi dan Karya Ulama Lokal di Kab. Majene Sulawesi Barat) ANNANGGURU ABDURRAHMAN QADIR (Biography Study and The Works of Local Islamic Cleric at Majene West Sulawesi)
}

\author{
Oleh: La Sakka*
}

* Peneliti pada Balai Penelitian dan Pengembangan Agama Makassar

Kantor: J1. A.P. Pettarani No. 72 Makassar

Rumah: J1. BTN Mangga 3 Blok F2 No 31 Makassar

\author{
Abstrak
}

Dewasa ini, kondisi sosial masyarakat Man hari tanpak semakin kehilanganfigur tauladan, dan semakin merindukan kehadiran sosok ulama sebagai penyejuk suasana sosialyang mudah tersulut amarah, penelitian ini bertujuan untuk mengungkap revitalisasi peran ulama dalam kehidupan masyarakat, dengan mengungkap biografi dan karya tulis Annangguru Abdurrahman Qadir di Majene secara deskriptif exploratif. Beliau memilikiperananpenting dalampenyebaran Tharikat Naqsyabandiyah di Majene karena beliau merupakan Mursyid Tharikat Naqsyabandiyah yang dipercayakan menyebarkan ajaran Tharikat Naqsyabandiyah di daerah tersebut. Pada silsilah Tharekat Naqsyabandiyah, ia merupakan mursyid^ang- ke-36 dengan menerima Ijazah dari Syekh Jalaluddinyang bermukim di Medan. Karya tulisnya adalah: 1) Pengantar Ilmu Syariat Batin Tharikat Naqsyabandiyah, 2) Risalah Pengantar Singkat Ajaran Tarekat Naqsyabandiyah dalam Suluk, 3) Mukhtar Fiqh al-Islam Jilid I dan Jilid II serta 4) Idha al-Mubham Jilid I dan Jilid II. Buku-buku tersebut walaupun berbeda tema, namun sama-sama bercirikan tasawuf yang merupakan pegangan bagi pengikut Tarikat Naqsyabandiyah. Buku-buku tersebut tak satupun yang pernah diterbitkan sehingga distribusi, pemanfaatan serta pelestariannya masih sangat terbatas pada orang-orang tertentu.

Rata kunci: Abdurrahman Qadir, Ulama Majene, Annangguru

\section{Abstract}

Today, the social conditions of society more and more lost of figure models, and thefigure missed the presence ofthe clergy as a social atmosphere conditioning easily ignited anger, the study aims to uncover the revitalization ofthe role ofscholars in public life, with biographies and writings reveal Annangguru Abdurrahman Qadir in Majene descriptively exploratif. $\mathrm{He}$ has an important role in the spread Tharikat Naqsyabandiyah in Majene because he is entrusted as a Murshid in Tharikat Naqsyabandiyah to spread this teachings in the area. On the genealogy Tharekat Naqsyabandiyah, he is a murshid of the 36th and receive the diplomafrom Sheik Jalaluddin who live in Medan. His writings are: 1) Introduction of Sharia In Tharikat Naqsyabandiyah, 2) A Brief Introduction to the Proceedings of the Doctrine of the Order Naqsyabandiyah Suluk, 3) Mukhtar al-Islam Fiqh Volume I and Volume II and 4) Idha al-Mubham Volume I and Volume II. Those books are even different themes, but equally characterized by Sufism which is a manual for followers Tharikat Naqsyabandiyah. Those books are none of them ever published so that the distribution, utilization and conservation is still very limited to certain people.

Key word: Abdurrahman Qadir, islamic cleric, Majene, annangguru

\section{PENDA H UL UA N}

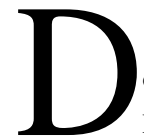

ari berbagai sumber (lontara dan tertulis) disebutkan, masuknya Islam di Kerajaan Majene/Banggae, Sendana, Pamboang, dan Malunda, melalui dua tahapan. Tahap pertama terjadi pada abad XV yaitu melalui pedagang-pedagang Kiuslim yang berdagang di daerah ini. Lewat cerekalah, Islam kemudian diperkenalkan kepada penduduk setempat. Hanya saja, metode ini kurang efektif karena tujuan utama para pedagang muslim tersebut adalah ekonomi dan bukan menyiarkan agama Islam.

Namun, sikap yang ditunjukkan para pedagang muslim dengan cara menghargai tradisi dan menghormati raja akhirnya mendapat simpati raja, sehingga pihak kerajaan pun memberikan perlindungan dan fasilitas kepada mereka. Meski begitu, belum terjadi konversi di pihak kerajaan maupun penduduk lokal. Pada tahapan kedua, yaitu abad XVI-XVII, barulah terjadi kontak antara penyebar agama Islam dengan 
masyarakat. Berbeda dengan tahapan pertama, penganjur agama Islam kali ini bukan berasal dari pedagang melainkan mereka betul-betul datang dengan maksud untuk menyebarkan agama Islam dalam hal ini ulama sebagai seorang yang ahli dalam agama Islam.' Peran besar ulamajuga berlaku pada beberapa proses islamisasi di beberapa daerah di Nusantara. Mereka bukan saja ahli dalam agama Islam. Namun, lebih dari itu mereka juga memegang peranan penting dalam kehidupan sosial masyarakat.

Kiai (ulama) sebagai pemimpin umat Islam telah mendapat sorotan dalam kajian-kajian para peneliti terhadap kepemimpinan Islam. Kajian-kajian tersebut mengakui bahwa kiai (ulama) adalah tokoh yang mempunyai posisi strategis dan sentral dalam masyarakat. Meskipun demikian, posisi-posisi penting apakah yang diperankan oleh mereka terdapat perbedaan sesuai dengan sudut pandang mereka. Geertz misalnya memandang kiai (ulama) sebagai makelar budaya (cultural brokers). Kiai sebagai mata rantai utama yang menghubunkan sistem lokal dengan keseluruhan sistem lebih besar. Ia telah memainkan peran perantara bagi umat Islam dengan memberi mereka pemahaman tentang apa yang sedang terjadi pada tingkat nasional. Sementara itu, Hiroko Horikoshi memadang ketokohan kiai bukan hanya sebagai mekelar budaya, sekedar perantara, tetapi lebih sebagai pemimpin tradisional yang memiliki kemampuan untuk menggerakkan orang-orang desa sesuai pengakuan mereka terhadap status dan peran kiai sebagai pemimpin masyarakat ${ }^{3}$

Abd. Kadir Ahmad menyoroti peran ulama (kiai) dari segi dinamika dan perubahan masyarakat. Peran terpenting ulama adalah mediator yang menghubungkan masyarakat dengan ajaran agamanya. Ulama mempertemukan antara energi budaya dari dalam masyarakat dengan input dinamika dari luar. Ulama melakukan transmisi budaya (dalam hal ini ajaran agama) ke dalam sistem sosial (masyarakat) dan membuat masyarakat bergerak dan dinamis sesuai dengan model yang diharapkan. Pada sisi lain, ulama juga menyerap dinamika yang berkembang di dalam masyarakat dan mentransformasikan budaya tersebut ke dalam budaya yang diyakininya.

Ulama sebagai warasatul ambiya merupakan elit agama yang mendapat pengakuan umatnya karena kedalaman ilmu agamanya dan ketinggian moral dan akhlaknya. Ia tampil sebagai pemimpin panutan, terutamadari segi keikhlasan dan dedikasinya. Ulama dalam konteks masyarakat Majene dikenal dengan sebutan Annangguru. Pengungkapan kembali biografinya selain memperkaya khazanah budaya dan keagamaan,juga dapat dijadikan patron moral dan etika dalam kehidupan masyarakat, dan dengan demikian merupakan salah satu bentuk pendidikan masyarakat ${ }^{4}$.

Di samping bimbingan langsung melalui dakwah dan pengajaran melalui pengajian (pesantren), karyakarya tulis ulama merupakan media transmisi dan transformasi keilmuan yang dengannya para ulama melaksanakan fungsinya sebagai pembimbing dan pengajar masyarakatnya. Dengan demikian keberadaan karya tulis itu sangat penting karena merupakan penyambung lidah para Annangguru kepada masyarakatnya .

Sehubungan dengan itu, ketika media cetak memperkenalkan dirinya, maka karya-karya ulama itu diperbanyak melalui media ini untuk memenuhi kebutuhan baca masyarakat. Berbagai kitab-kitab bernilai tinggi dari segi bobot keilmuannya serta dari segi bahasa pengantarnya yang komunikatif tersebar dalam jangkauan yang luas. Disamping itu, banyak karya-karya ulama, terutama ulama lokal yang berbobot tinggi, tetapi dengan bahasa dan aksara lokal maka persebarannya terbatas. Karya-karya tulis demikian ini banyak yang sudah terlupakan oleh masyarakat,

Ahmad \& Marjanah. 2007. Sejarah dan Kebudayaan Mandar Jilid II: Sejarah Mandar dan Sejarah Perjuangan Bangsa. Majene: Dinas Pendidikan Kabupaten Majene, h.72-74.

Endang Tarmudi. 2003,. Perselingkuhan Kiyai dan Kekuasaan, ogjakarta: LKiS, h. 2. juga lihat, Abd. Kadir Ahmad. 2008. Ulama Bugis, Makassar: Indobis, h. 1-2

Horkosi. 1987. Kiyai dan Perubahan Sosial. Jakarta: P3M, h. 241

"wawancara dengan Pak Maksum (khalifah Tarekat Naqsyabandiyah di Majene) pada tanggal 27 Februari 2011, pada pukul 16.00 s/d. 17.45 sesudah Isya di rumah kediamannya. H.Maksum membenarkan pemberian informasi tentang kehadiran Ruh Annangguru Abdurrahman Qadir dalam beberapa peristiwa seperti yang dicentakan di atas.

Qadir, Abdurrahman. 1987. Risalah Pengantar Singkat (Rispengsi) Ajaran Tharekat Naksyabandiyah Dalam Suluk. Jilid II. t.p, h. $22-23$. 
minimal tersimpan dalam rak-rak buku tanpa tersentuh, >ang pada gilirannya akan terancam kepunahannya.

Karya-karya lokal tersebut merupakan bahagian :ari khazanah budaya dan kekayaan intelektual bangsa $>$ ang seharusnya mendapatkan perhatian yang tinggi. Namun karena nilai ekonominya relatif rendah karena ?erbagai faktor sehingga tidak medapatkan perhatian selayaknya. Karena itu, Balai Litbang Agama Makassar, atas dasar keperhatinannya akan hilangnya vhazanah budaya keagamaan, merasa perlu untuk iemberikan perhatian yang serius. Ia merasa perlu - enginventarisir karya-karya ulama itu dan -.emperkenalkannya lebih luasmelaluideskrepsiyang komunikatif

Kenyataan tersebut tentang besarnya peran ulama irjadijuga pada proses Islamisasi dan perkembangan agama Islam di Kabupaten Majene. Terdapat ceberapa versi mengenai proses masuknya Islam di 3 anggae. Namun, semuanya itu menunjuk pada satu ama tokoh sentral yakni Syekh Abdul Mannan. Darmawan Masud Rahman, seperti dikutip

hammad Rais, mengatakan, Abdurrahim Kamaluddin (penganjur Islam di Balanipa), terpaksa ::dak melanjutkan perjalanan dakwahnya ke Majene hanya berjarak $7 \mathrm{Km}$ dari Balanipa) karena dalam aktu bersamaan Abdul Mannan juga tengah rnenyiarkan Islam di daerah tersebut.

Dengan realitas seperti itu di atas, telah nyata ?eran ulama dalam perkembangan Islam di Majene. Pada generasi selanjutnya sampai zaman kemerdekaan peran ulama semakin nyata dengan berdirinnya $\wedge$ berapa organisasi, perguruan yang bercirikan Islam, kesemuanya dipelopori oleh ulama.

Berdasarkan latar belakang di atas penelitian ini akan membahas salah seorang ulama yang di Majene 1 aitu Abd. Rahman Qadir yang merupakan salah satu ulama yang membina ajaran tarekat naqsyabandiyah. Pemilihan terhadap tokoh Abd. Rahman Qadir berdasarkan hasil penjajakan dimana beliau merupakan salah satu ulama yang memiliki beberapa karya tulis.

Berdasarkan latar belakang di atas, pokok asalah dalam penelitian ini yaitu: Bagaimana biografi '.nnangguru Abdurrahman Qadir dan karya tulisnya sebagai ulama di Kabupaten Majene? Pertanyaan ini ljabarkan dalam sub permasalahan sebagai berikut:

Bagaimana Kehidupan pribadi Annanguru Abdurrahman Qadir?
2. Bagaimana karya-karya tulis Annangguru Abdurrahman Qadir?

Berangkat dari masalah penelitian yang telah dikemukakan, penelitian ini bertujuan untuk:

1. Menyusun biografi Annangguru Abdurrahman Qadir, meliputi: identitas pribadi, pendidikan, aktivitas dan sikap keagamaannya;

2. Menginventarisir karya tulis Annanguru Abdurrahman Qadir yang diketemukan, baik berupa buku keagamaan, artikel, makala ilmiyah, maupun karya tulis lainnya; dan membuat dekrepsinya berupa anotasi buku, meliputi berbagai aspek;

Hasil Penelitian ini diharapkan berguna bagi:

1. Jajaran Kementerian Agama dan instansi lainnya yang berkepentingan sebagai data-data keagamaan yang dapat dijadikan pertimbangan dalam pengambilan kebijakan pembangunan di bidang agama;

2. Para akademisi, pencinta ilmu, serta pihak-pihak lainnya sebagai informasi awal bagi mereka untuk menentukan langkah-langkah selanjutnya;

3. Penambahan lektur keagamaan yang dapat dijadikan bacaan atau rujukan.

\section{PEM B A H A S A N}

\section{Riwayat Hidup Annanguru Abdurahman Qadir}

\section{Silsilah dan Riwayat Hidupnya}

Kampung Saleppa merupakan tempat kelahiran almarhum Annangguru Abdurrahman Qadir yang merupakan salah satu kampong di wilayah Kabupaten Majene. Abdrurrhahman Qadir dilahirkan pada hari Senin tanggal 31 Desember 1917. Beliau merupakan anaktunggal dari pasangan ayah bernamaAbd. Qadir Atjo dan ibu bernama Barunna.

\section{Riwayat Pendidikannya}

Ketika berusia 7 tahun Abdurrahman memulai pendidikannya seperti anak-anak lainnya di masanya. Dia bersekolah di Sekolah Gubernamen (Sekolah Dasar, zaman Belanda) tamat pada tahun 1930 di Majene, dan beliau juga menamatkan pendidikannya di PGA 6 Tahun di majene, dan selesai pada tahun 1954. Perguruan Sekolah Islam Tinggi Makkah/ Madinah Jurusan Falsafah Ilmu Tauhid Tahun 1393 
H/1973 M. Selanjutnya ia mendapat gelar professor dalam bidang Tariqat dari Universitas Imam Ghazali Jurusan Falsafah Ilmu Tauhid pada tahun 1975 di Medan

Di samping pendidikan formal di atas, Abdurrahman Qadirjuga menempuh pendidikan non formal (tradisional) dengan belajar kepada Syekh Hasan al-Yamani d,i Campalagian selama kurang lebih 10 tahun dengan mempelajari ilmu Musthalah Hadits, ilmu Tafsir, Ushul Fiqhi, Ilmu Fiqhi, Ilmu Bahasa Arab dan Qawaidnya.

\section{Riwayat Perkawinanna}

Selama hidupnya, Abdurrahman Qadir pernah menikah dua kali. Pernikahan pertamanya pada tahun 1941 dengan salah seorang wanita dari kalangan keluarganya yang bernama Husna. Dari hasil pernihakannya ini beliau dikaruniai dua orang putra, yakni: Muhammad Saudi yang lahir pada tahun 1948 dan Wahidin lahir pada tahun 1952.

Sedangkan untuk pernikahan yang kedua pada tahun 1954 dengan seorang perempuan bernama St. Hadijah beliau dikaruniai lima orang anak (3 putri dan 2 putra), yaitu: a) Nurhayati, lahir pada tahun 1954, b) Rusdiyah lahir pada tahun 1958, c) Nasrafuddin, lahir pada tahun 1961. d) Nurjannah lahir pada tahun 1964 e) Mukhtar S.Ag, lahir pada tahun 1974

\section{Riwayat Pekerjaannya.}

Abdurrahman Qadir merupakan Mursyid pada silsilah ke-36 dalam Tariqat Naqsyabandiyah. Ia diberi gelar kehormatan Shultanul Auliyah Mursyid Kammil Mukammal Prof. Dr. K. S yyekh. H. Abdurrahman Qadir wakil Utama dari Dr. Syekh Jalaluddin. Beliau diamanatkan untuk mengajarkan 17 tingkat mata pelajaran tarikat di daerah Republik Indonesia. Hal ini merupakan bagian dari kepercayaan Syekh Jalaluddin kepada beliau, sebab 40 hari lamanya mengajarkan tarikat Naksyabandiah (TN) di Jakarta.

Di samping dikenal sebagai Mursyid, beliau pernah menduduki beberapajabatan penting dalam organisasi pemerintahan dan sosial antara lain:

a. Anggota Mahkamah Syari'yah Majene pada tahun 1942 s/d 1951,

b. Anggota Sidang Pengadilan Agama pada tahun $1962 \mathrm{~s} / \mathrm{d}$

c. Anggota DPRD-GR mulai pada tanggal 23-91961 s/d 1-8-1965 di Majene d. Anggota DPRD pada tanggal 4-10-1968 s/d 1010-1970 di Majene

e. Anggota DPRD Propinsi Dati I Sulawesi Selatan hasil Pemilu tahun 1971

f. Pegawai Negeri Sipil Pada Kantor Urusan Agama Kab. Majene (1951 sampai pensiun pada tanggal 31 -12 -1973 pada kantor tersebut)

g. Dalam Organisasi PPTI ( Persatuan Pembela Tarekat Islam), diangkat menjadi Konsul PPTI Cabang Majene pada tahun 1963 s/d 1970

h. Pembantu Umum PB. PPTI Pusat Jakarta pada tanggal 1-12-1967 s/d 28-7-1976

i. Konsul Jenderal PPTI MajelisDa'wah Sulawesi Selatan 1-5-1968 s/d

j. Ketua Umum Perwakilan DPP.PPTI Golkar untuk Indonesia bagian Timur 2 8-7-1976 s/d

k. Ketua Umum/Ketua Dewan Mursyidin PB.PPTI-Golkar sejak

1. Ketua Panitia Kongres Nasional PPTI-Golkar yang diselenggarakan / dibuka^iada tanggal $26 \mathrm{~s} /$ d 29 juli 1976 di Majene

\section{Perjuangan dan kiprah Abdurrahman Qadir di Bidang Pendidikan dan Dakwah}

Sejak kecil, Abdurrahman Qadir dikenal sebagai seorang ulet dan cerdas. Beliau juga dikenal mememiliki keistimewaan (karamah). Ia sering dijumpai muridnya bersama melaksanakan shalat di suatu mesjid namun pada waktu yang bersamaanjuga terlihat wajah beliau di tempatyang lain.

Oleh beberapa koleganya, ia dikenal sebiagai seorang pendiam namun sangat serius dan bertanggung jawab terhadap tugas-tugas yang diemban. Kepribadian tersebutjuga tergambar dalam kiprahnya menyebarkan dan mengajarkan ajaran Tarekat Naqsyabandiyah di Kabupaten Majene. Oleh karena misi tersebut, ia membuat majlis zikir dan pengajian di rumahnya sendiri sekaligus dan pesantren (pondokan) disamping rumah maraddia majene (bapaknya pua tonra). Hanya saja pesantren tersebut masih bersifat tradisional non formal. Murid-muridnya berasal dari daerah di Majene dan sekitarnya. 


\section{Annangguru A bdurrahman \\ Kh a lifa hTh ariqat Naqsyabandiyah}

Tarikat Naqsyabandiyah didirikan oleh Imam Tariqat Hadhrat Khwajah Khwajahgan Sayyid Shah Muhammad Bahauddin Naqshband Al-Bukhari AlUwaisi Rahmatullah 'alaih, dilahirkan pada bulan Muharram tahun 717 Hijrah bersamaan 1317 Masihi iaitu pada abad ke 8 Hijrah bersamaan dengan abad ke 14 Masihi di sebuah perkampungan bernama Qasrul 'Arifan berdekatan Bukhara. Ia menerima pendidikan awal Tariqat secara Zahir dari gurunya Hadhrat Sayyid Muhammad Baba As-Sammasi Rahmatullah 'alaih dan seterusnya menerima rahsia-rahsia Tariqat dan Khilafat dari Syeikhnya, Hadhrat Sayyid Amir Kullal Rahmatullah 'alaih. Ia menerima limpahan Faidhz dari Hadhrat Nabi Muhammad Rasulullah Sallallahu 'Alaihi Wasallam menerusi Hadhrat Khwajah Khwajahgan 'Abdul KhaliqAl-Ghujduwani Rahmatullah 'alaihyang telah 200 tahun mendahuluinya secara Uwaisiyah.

Naqsyabandiyah merupakan salah satu tarekat sufi yang paling luas penyebaran nya, dan terdapat banyak di wilayah Asia Muslim (meskipun sedikit di antara orang-orang Arab) serta Turki, BosniaHerzegovina, dan wilayah Volga Ural. Bermula di Bukhara pada akhir abad ke-14, Naqsyabandiyah mulai menyebar. ke daerah-daerah tetangga dunia Muslim dalam waktu seratus tahun. Perluasannya mendapat dorongan baru dengan mftnculnya cabang Mujaddidiyah, dinamai menurut nama Syekh Ahmad Sirhindi Mujaddidi Alf-i Tsani ("Pembaru Milenium kedua", w. 1624). Pada akhir abad ke-18, nama ini hampir sinonim dengan tarekat tersebut di seluruh Asia Selatan, wilayah Utsmaniyah, dan sebagian besar Asia Tengah. Ciri yang menonjol dari Tharikat Naqsyabandiyah adalah diikutinya syari'at secara ketat, keseriusan dalam beribadah menyebabkan penolakan terhadap musik dan tari, serta lebih mengutamakan berdzikir dalam hati, dan kecenderungannya semakin kuat ke arah keterlibatan dalam politik (meskipun tidak konsisten).

Pada silsilah Tharikat Naqsyabandiyah, Syekh Abdurrahman Qadir merupakan khalifah yang ke36. Beliau menerima ijazah dari Syekh Jalaluddin di Medan untuk mengajarkan ajaran Tharikat Naqsyabandiyah di daerah Majene setelah beliau mendapat kepercayaan mengajarkan ajaran tersebut selama 40 hari di Jakarta. Berikut ini silsilah Tharikat Naqsyabandiyah sampai ke Syekh Adurrahman Qadir:
1. Muhammad Rasulullah saw

2. Abu Bakar al-Shiddiq ra.

3. Salman al-Farisy ra.

4. Kasim bin Muhammad bin Abu Bakar ra.

5. Imam Ja'far Shadiq ra.

6. Abu Yazid al-Bustami ra.

7. Abu Hasan Harkany ra.

8. Abu Ali Farmady ra.

9. Syekh Yusuf Hamdani qs. (Qaddasallah Sirrah)

10. Syekh Abdul Khaliq Fajduanyqs.

11. Syekh Arif al-Riaukary qs.

12. Syekh Muhammad al-Anjiryqs.

13. Syekh A1 i al-Ramitamy

14. Syekh Muhammad Babassamasy

15. Syekh Amir Kulaly

16. Syekh Bahauddin Naqsyabandy

17. Syekh Muhammad Alauddin

18. SyekhYakub al-Jatkhy

19. Syekh Ubaidillah Ahrari Samarkandi

20. Syekh Muhammad Zahidy

21. Syekh Darwis Muhammad

22. Syekh Muhammad Hawajaky al-Amkany

23. Syekh Muhammad Baki Billah

24. Syekh Ahmad Faruky Sarhimidy

25. Syekh^Muhammad Maksum

26. Syekh Muhammad Saefuddin

27. Syekh Muhammad Syekh Nur Badawani

28. Syekh Syamsuddin Habibullah Jaan Jaanaany

29. Syekh Abdullah al-Dahlawy

30. Syekh Khalidil Kurdy

31. Syekh Abdullah Affandy

32. Syekh Sulaimanul Kurmy

33. Syekh SulaimanZuhdy

34. Syekh Ali Ridha di Jabal Qubis Mekah

35. Syekh Jalaluddin

36. Syekh Abdul Qadir Rahman ${ }^{4}$ 


\section{Karya Tulis Annanguru Abdurrahman Qadir}

Semasa hidupnya, Annangguru Abdurrahman Qadir memiliki beberapa karya tulis. Uniknya bila dilihat dari sisi konten, buku-buku tersebut bervariasi dalam beberapa disiplin ilmu seperti tarekat, tauhid dan fiqh. Akan tetapi semua karya-karya beliau pada umunya bercorak tasawuf. Hal ini sesuai dengan latar belakang beliau sebagai Mursyid Tarekat Naqsyabandiyah. Buku- buku atau Karya Tulisan beliau antara lai sebagai berikut:

\section{Pengantar Ilmu Syariat Batin (Peisbat) Tarikat Naksyaband, Jilid I tahun 1987M.}

Pengantar Ilmu Syariat Batin Tariqat naqsyabandiyah sebuah karya yang di dalam di bahas masalah; Adab-adab sebelum suluk, Adab-adab dalam suluk, Adab-adab sesudah suluk, Adab-adab siswa Terhadap Syedkh Mursyid, Adab-adab siswa kehadapan Syedkh Mursyidnya dalam Tarikat Naksyhabandiah, Adab-adab siswa terhadap sesamanya, yang disebut ukhuwsah islamiyah, Adabadab siswa/mahasiswa khusus dirinya, Pembaiatan dalam tarikat Naksyabandiah ( $\mathrm{T} \mathrm{N}$ ), Kaifiat Mandi Tobat, Tawajjuh oleh syeikh mursyid, Dzikir ismudzzat, DzikirNafty itsbaat, Dzikir wukuf, Murakabah Mutlak, Murakabah Ahadiyatul Fi'ail, Murakabah Ma'iyah, Murakabah Akrabiyah, Murakabah Ahadiyahtydzzat, Murakabah Dzatusshorfi Wal-Bahti, Maqam Musyahadah, Maqam Mukassyafah, Maqam Muqabalah, Maqam Mukafahah, Maqam Fanaa Fillah, Maqam Baqa Billah, Takhlilullisan tujuh khatam, Takhlilullisan, Dzikir Nafas serta beberapa pembahasan lainnya yang berkaitan dengan Tarekat Naqsyabandiyah.

Risalah Pengantar Singkat (Rispengsi ) Ajaran Tharekat Naksyabandiyah Dalam Suluk, Jilid II

Buku ini berisi tentang; Hakikat Thariqat Naqsyabandiyah, Arti Suluk dalam Thariqat Naqsyabandiyah, Syarat-syarat, Suluk, Dzikir Lataif, Syarat Dzikir Nafy Itsbat, Dzikir Wukuf, Muraqabah dalam Tharikat Naqsyabandiyah, Muraqabah Mutlak, Muraqabaha Ahadiyatul Af'al, Muraqabah Ma'iyyah, Muraqabah Akrabiyah, Murakabah Dzatussarfi wal Bahti, Maqam dalam Thariqat Naqsyabandiyah, Maqam $\begin{array}{lrrr}\text { Musyahadah, } & \text { Maqam } & \text { Mukasyafah, } & \text { Maqam } \\ \text { Muqabalah, } & \text { Maqam } & \text { Mukafahah, Maqam fana' }\end{array}$ Fillah, Maqam Baqa'Billah, Tahlil Tujuh Khatam dan Syarat-syaratnya, Adab-adab sesudah Suluk, Rahasia-rahasia Silsilah, Thariqat Islam yang ressmi serta Penerimaan Thariqat Naqsyabandiyah dari Silsilah ke 35 Syekh H. Jalaluddin oleh Syekh Abdul Rahman Qadir.

Mukhtarul Fiqhul Islamii Jilid I di tulis pada tahun 1979/1399 H, jumlah halaman ada 207 halaman. Ukuran $16.3 \times 10 \mathrm{~cm}$,

Mukhtar Fiqh Islam Jilid I merupakarukarya beliau di bidang fiqh dengan konten sebagai berikut; Altaharah, meliputi pembagian air, serta macam taharah yaitu: istinja', membersihkan dari najis, wudhu, tayammum dan mandi beserta beberapa penjelasan yang berkiatan dengannya.

Pada bagian selanjutnya membahas seputar; Shalatyang meliputi pembahasan waktu-waktu shalat fardhu dan hukum orang yang melaksanakan shalat di luar waktu, orang yang meninggalkan shalat, pembahasan tentang azan dan iqamat, pembahasan tentang menutup aurat serta pakaian yang diperbolehkan dipakai dalam shalat, tempat-tempat diperbolehkan melakukan shalat serta pembahasan tentang masjid, syarat sah shalat serta bentuk shalat shalat yang meliputi amalan-amalan dalam shalat (baik itu baik itu amalan rukun maupun sunnah).

Mukhtarul Fiqhul Islamii Jilid II di tulis pada tahun 1983 M /'1404 H. jumlah halaman ada 171 halaman. Ukuran kertas $16.3 \times 10 \mathrm{~cm}$.

Buku ini merupakan lanjutan dari Mukhtar Fiqh Islam jilid I dengan pembahasan yaitu seputar shalat meliputi;

1) Hal-hal yang membatalkan shalat,

2) Macam-macam shalat sunnah seperti shalat rawatib, shalat witir, shalat qiyam al-lail, shalat tarwih, shalat dhuha, shalat Tahiiyat Masjid, shalat setelah bersuci.

3) Waktu-waktu dilarang melakukan shalat

4) Sujud Tilawah dan sujud Syukur.

5) Sujud Sahwi 
6) Kewajiban Shalat Berjama'ah

7) Keutamaan Shalat di Masjid

8) Imamah dalam Shalat

9) Tatacara shalat orang sakit

10) Shalat dalam perjalanan termasuk pembahasan shalat jama' dan qashar

11) Celaan bagi yang meninggalkan shalat Jum'at

Idhahul Mubham (I) di tulis pada tahun 1979 M / 1399 H.ada 117 halaman. Ukuran 16.3 x $10.5 \mathrm{~cm}$.

Kitab ini membahas seputar ilmu Tauhid dengan bercorak tasawuf. Materi yang dibahas dalam kitab ini yaitu: Tauhid kepada Allah beserta beberapa pendapat Tauhid, al-farq waljam', al-yaqin wal adwam, Maqam-maqam para salik, memperoleh derajat makrifat, Akidah Ahlu Sunnah wal Jama'ah pada 2 kalimat Syahadat menurut Imam Al- Gazali dan Imam Al-Asy'ariy dan penjelasan Al-Qur'an dan Hadis seputar masalah Tauhid.

Idhahul Mubham (II) di tulis pada tahun 1983M/ $1404 \mathrm{H}$, ada 196 halaman. Ukuran $16.3 \times 10.5$ cm.

Kitab ini merupakan lanjutan dari Idhah alMubham Jilid I. Materi yang dibahas dalam kitab ini yaitu: Masyi'ah dan Iradah, Iradah dan Ridha, Ilmu Tauhid serta kewaj iban mengetahui dan larangan taqlid dalam tauhid, kelompok-kelompok yang tetap dalam agama Islam, lahirnya aliran Muktazilah, hukum bagi yang menghalal, mengharamkan, menatapkan Islam dan kafir terhadap seseorang, syirik besar, ruqyah dan tamimah yang diperbolehkan dan diharamkan, memohon berkah kepada pohon, batu dana selainnya serta pembahasan hal-hal yang mengakibatkan perbuatan syirik kepada Allah swt.

\section{PEN U T UP}

\section{Kesimpulan}

Dari tersebut di atas, dapat ditarik kesimpulan sebagai berikut:

1. Abdurrahman Qadir merupakan salah seorang ulama lokal kharismatik yang berasal dari Kabupaten Majene Propinsi Sulawesi Barat. Beliau memiliki peranan penting dalam penyebaran Tarikat Naqsyabandiyah di Majene karena beliau merupakan Mursyid Tarikat Naqsyabandiyah yang dipercayakan menyebarkan ajaran Tarikat Naqsyabandiyah di daerah tersebut. Pada silsilah Tarekat Naqsyabandiyah, ia merupakan mursyid yang ke36 dengan menerima Ijazah dari Syekh Jalaluddin yang bermukim di Medan.

2. Dari hasil penelusuran, ada beberapa karya atau tulisan beliau yang diinventarisasi yaitu Pengantar Ilmu Syariat Batin Tarikat Naqsyabandiyah, Risalah Pengantar Singkat Ajaran Tarekat Naqsyabandiyah dalam Suluk, Mukhtar Fiqh alIslam Jilid I dan Jilid II serta Idha al-Mubham Jilid I dan Jilid II. Buku-buku tersebut walaupun berbeda tema, namun sama-sama bercirikan tasawuf. Buku-buku tersebut merupakan pegangan bagi pengikut Tarikat Naqsyabandiyah. Hanya saja dari semua buku tersebut, tak satupun yang pernah diterbitkan oleh sebuah penerbit buku sehingga distribusi, pemanfatan serta pelestariannya masih sangat terbatas pada orangorang tertentu.

\section{Rekomendasi}

Berdasarkan kesimpulan tersbut di atas, penelitian ini merekomendasikan:

1. Sebagaimana pada pembahasan di.atas bahwa Annangguru Abdul Rahman Qadir adalah ulama Tarekat Naqsyabandiyah sekaligus tokoh masyarakat yang aktif dalam lembaga sosial maupun pemerintahan, maka diperlukan adanya pengkajian atau penelitian secara mendalam terhadap pribadi serta peran sosial Annangguru Abdul Rahman Qadir.

2. Karya-karya Annangguru Abdul Rahman Qadir merupakan karya yang bernilai sangat tinggi khususnya di kalangan pengikut Tarekat Naqsyabandiyah di Kabupaten Majene. Hanya saja karya-karya tersebut belum satupun yang diterbitkan oleh sebuah penerbit. Oleh karena itu, direkomendasikan kepada Puslitbang Lektur Keagamaan atau Balai Litbang Agama Makassar sebagai Unit Pelaksana Teknis Badan Litbang dan Diklat Kementerian Agama, agar mengupayakan 
pencetakan dan penerbitan karya beliau sehingga dapat dimanfaatkan oleh akademisi khususnya pengikut Tarekat Naqsyabandiyah itu sendir

\section{UCA PA N T E R I MA KASIH}

Dengan segala syukur atas dimuatnya tulisan ini di jurnal Al Qalam, maka secara pribadi saya mengucapkan terima kasih yang tak terhingga kepada pengelolajurnal atas dimuatnya tulisan ini. Selan itu, saya ucapkan banyak terima kasih kepada keluarga Annangguru Abdurrahman Qadir yang telah banyak memberikan informasi selama penelitian ini.

\section{A F T A R P U S T A K A}

Ahmad dan Marjanah. 2007. Sejarah dan Kebudayaan Mandar Jilid I. Sejarah Mandar dan Sejarah Perjuangan Bangsa di Kabupaten Majene. Majene: Dinas Pendidikan dan Kebudayaan Kabupaten Majene.

Badan Pusat Statistik Kabupaten Majene. Kabupaten Majene dalam Angka 2010.

http://id.wikipedia.org/wiki/Tarekat Naqsvabandivah. diakses tanggal 15 April 2011

Qadir, Abdul Rahman. 1987. Pengantar Ilmu Syariat Batin (Peisbat) Tarikat Naksyabandiyah, Jilid I. t.p.

1987. Risalah Pengantar Singkat (Rispengsi) Ajaran Tharekat Naksyabandiyah Dalam Suluk. Jilid II. t.p. 1979. Mukhtarul Fiqhul Islamii. Jilid I. t.p.

1983. Mukhtarul Fiqhul Islamii. Jilid I. t.p.

1979. Idhahul Mubham. Jilid I. t.p.

1983. Idhahul Mubham. Jilid I. t.p.

Wawancara:

Maksum (khalifah Tarekat Naqsyabandiyah di Majene) pada tanggal 27 Februari 2011, padapukul 16.00 s/d. 17.45 